\title{
Refuge
}

Canada's Journal on Refugees

revue canadienne sur les réfugiés

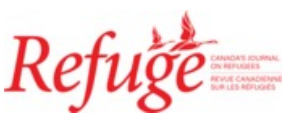

\section{Invisible Lives: Gender, Dispossession, and Precarity amongst Syrian Refugee Women in the Middle East}

\section{Nergis Canefe}

Volume 34, numéro 1, 2018

Intersectional Feminist Interventions in the "Refugee Crisis"

URI : https://id.erudit.org/iderudit/1050853ar

DOI : https://doi.org/10.7202/1050853ar

Aller au sommaire du numéro

Éditeur(s)

Centre for Refugee Studies, York University

ISSN

0229-5113 (imprimé)

1920-7336 (numérique)

Découvrir la revue

Citer cet article

Canefe, N. (2018). Invisible Lives: Gender, Dispossession, and Precarity amongst Syrian Refugee Women in the Middle East. Refuge, 34(1).

https://doi.org/10.7202/1050853ar
Résumé de l'article

Cet article concerne les connexions entre les régimes de travail néo-libéraux et néo-développementistes, la gestion de l'asile et de l'immigration, et

l'exploitation de femmes migrantes, réfugiées, sans papiers, à partir du vécu de réfugiées syriennes en Turquie. Le concept de précarité est exploré en tant que stratégie appliquée de manière sélective par les états aux personnes qui n'ont " pas de statut » ou ne peuvent pas bénéficier de «droits d'appartenance ». Les migrants forcés, les migrants illégaux et les demandeurs d'asile sont directement concernés par des expériences de travail fortement précaire au plus bas des marchés du travail sur l'ensemble des pays du Sud, et deviennent alors prisonnier du travail forcé et du trafic d'êtres humains. L'article établit un lien entre des formes extrêmes d'exploitation des migrants au travail dans des contextes de vie précaires et un profilage des opportunités de vie en fonction du genre.
Copyright (c) Refuge: Canada’s Journal on Refugees, 2018

Creative Commons Attribution NonCommercial 4.0 International License
Ce document est protégé par la loi sur le droit d'auteur. L'utilisation des services d'Érudit (y compris la reproduction) est assujettie à sa politique d'utilisation que vous pouvez consulter en ligne.

https://apropos.erudit.org/fr/usagers/politique-dutilisation/ 


\title{
Invisible Lives: Gender, Dispossession, and Precarity amongst Syrian Refugee Women in the Middle East
}

\author{
NERGIS CANEFE
}

\section{Abstract}

This article attends to the connections between neo-liberal and neo-developmentalist labour regimes, asylum and immigration management, and the exploitation of undocumented, refugee, and migrant women, based on the experiences of Syrian refugee women in Turkey. The concept of precarity is explored as a selectively applied strategy by states to people who lack "status" or who are unable to benefit from "membership rights." Forced migrants, illegal migrants, and asylum seekers are directly implicated in highly precarious work experiences at the bottom end of labour markets across the Global South, becoming trapped in forced labour and human trafficking arrangements. The article establishes a link between extreme forms of migrant labour exploitation in precarious life worlds and genderbased profiling of life chances.

\section{Résumé}

Cet article concerne les connexions entre les régimes de travail néo-libéraux et néo-développementistes, la gestion de l'asile et de l'immigration, et l'exploitation de femmes migrantes, réfugiées, sans papiers, à partir du vécu de réfugiées syriennes en Turquie. Le concept de précarité est exploré en tant que stratégie appliquée de manière sélective par les états aux personnes qui nont "pas de statut»ou ne peuvent pas bénéficier de "droits d'appartenance». Les migrants forcés, les migrants illégaux et les demandeurs d'asile sont directement concernés par des expériences de travail fortement précaire au plus bas des marchés du travail sur l'ensemble des pays du Sud, et deviennent alors prisonnier du travail forcé et du trafic d'êtres humains. Larticle établit un lien entre des formes extrêmes d'exploitation des migrants au travail dans des contextes de vie précaires et un profilage des opportunités de vie en fonction du genre.

\section{Introduction}

I n 2003 the concept of precarity emerged as the central organizing platform for a series of social struggles that would spread across Europe. ${ }^{1}$ However, to understand precarity as a political concept rather than simply as a form of labour exploitation, it is necessary to go beyond economistic approaches that see social-political conditions of populations subjected to this form of structural violence. ${ }^{2}$ Such a move in effect requires us to see precarity as the norm and regularized labour as the exception. This conceptual move enables us to frame the precarity of labour, in particular migrant labour, in a broader historical and geographical perspective, shedding light on its relation to the phenomena of precarious lives. In this regard, novel forms of subjectivization observed during
(C) Nergis Canefe, 2018. This open-access work is licensed under a Creative Commons Attribution-NonCommercial 4.0 International Licence, which permits use, reproduction, and distribution in any medium for non-commercial purposes, provided the original authorship is credited and the original publication in Refuge: Canada's Journal on Refugees is cited.
Cette ouvre en libre accès fait l'objet d'une licence Creative Commons Attribution-NonCommercial 4.o International License, laquelle autorise l'utilisation, la reproduction et la distribution de l'œuvre sur tout support à des fins non commerciales, pourvu que l'auteur ou les auteurs originaux soient mentionnés et que la publication originale dans Refuge: revue canadienne sur les réfugiés soit citée. 
and after processes of dispossession effected by forced migration are themselves inherently precarious, often trans-border undertakings targeting migrants, stateless people, and sanspapiers. ${ }^{3}$ As argued by Rygiel, ${ }^{4}$ our current understanding of precarity is insufficient to describe the specific challenges of non-citizen and undocumented lives. We need a shift of lens, and far from being focused on the way precarity manifests itself in the workplace, we must concentrate on the challenges posed by residence and legal status, or lack thereof, for migrants and refugees. The nebulous class quality of the concept would then come to benefit such a reframing. With the exponential growth of civil war in Syria since 2011, the refugee crisis in the Middle East has escalated sharply, and its impact is widening from neighbouring countries towards Europe. This article describes the emergence of a special kind of labour market in sectors that are often designated as informal, marginal, and worse, as non-labour for Syrian women migrants and refugees scattered across the Middle East since 2011.5

Indeed, there has been precious little attention paid to the quality of work life with which such precarious livelihoods are associated. This article considers several features of Syrian migrants' and refugees' work lives that are disproportionately oppressive. In particular, I propose that we use "gender" as a constitutive category to understand experiences of Syrian forced migrants in the Middle East. In addition to definitive elements of precarious or non-standard employment, Syrian women experience life-changing events that are largely invisible: early forced marriages, human trafficking to prostitution, and becoming second/clandestine wives to local men in the host society. ${ }^{6}$ While different tracks of survival that affect both Syrian men and women have existential conditions in common, there isn't enough commonality to forge a genderless depiction of Syrian refugees and migrants' absorption to precarity. ${ }^{7}$

In the following pages I first chart the engagement of Middle Eastern states with the ongoing Syrian refugee crisis and contextualize the response of the Turkish state to the exodus as the main recipient of the displaced Syrians accordingly. ${ }^{8}$ The purpose of this exercise is to understand why the outbreak of the region's largest refugee crisis since the Second World War, exceeding even the Palestinian one, did not prompt the neighbouring states to accede to standard, restrictive renditions of international refugee law or border closures. ${ }^{9}$ Reception of Syrian refugees in contemporary Turkey is the latest example of the collapse of border protection fantasies so strongly embraced in the Global North. ${ }^{10}$ The Syrian exodus indicates the amalgamation of forced migration flows with emergent forms of developmentalism in the region, with marked gender-based subjectification of non-status people. ${ }^{11}$ In this regard, the article will first discuss the generic meaning of precarious labour and then apply it to the forced migration context. It will then highlight key areas of gender-specific forms of subjugation affecting Syrian refugee and migrant women in order to identify the gaps in the literature on precarity in the Middle East.

This article contributes a detailed exploration of the specific pathways through which socio-legal status (i.e., "asylum seeker," "refused asylum seeker," "temporary residence," "guest-worker," etc.) and gender identity are combined to shape experiences of forced labour and the conditions leading to exploitative work. It also reconsiders different meanings and interpretations of forced labour vis-à-vis forced migration. ${ }^{12}$ Here the concept of precarity denoting lived experiences characterized by uncertainty and instability is used to help understand the key factors and processes that render Syrian refugees and migrants more vulnerable to both forced labour and lives marked by indignities.

\section{Gender, Asylum, and Precarity in the Middle East}

The topic of forced labour is receiving growing political and policy attention across the globe. Regardless of the specific national and regional context, compromised socio-legal status of immigrants and refugees resulting from restrictive immigration policy, neo-liberal labour market regulations and migrants' own trajectories normalize precarious work. In this context, using precarity as a lens to examine forced labour encourages the recognition of extreme forms of exploitation as part of a wider picture of systematic exploitation of migrants in the global labour market. The concept of hyper-precarity is then used to explain how multidimensional insecurities contribute to forced labour experiences.

Before discussing hyper-precarity in detail, however, it is important to revisit the concept of precarity itself. In addition to the rich literature on labour precarity, Judith Butler's work on precarious life is worthy of particular mention in this context. ${ }^{13}$ Underlining the inherent vulnerability of the individual in late-capitalist societies, Butler takes the bold step of considering all human life precarious. Precariousness in this sense implies our dependency upon others and the full exposure of bonds between individuals. All human existence is interdependent and thus precarity invites us to rethink our responsibility concerning the lives of others. In the context of political cultures in post-9/11 America, Butler then submits that enhancing the precariousness of some at the expense of others has become the defining feature of new frames of war in the age of presumed global terrorism. The resultant experience of enhanced precariousness created by the select operations of power, such as those generated by prevailing discourse in post-9/11 America, is what Butler calls "precarity." In this way, she purports that encounters with precariousness and precarity hold new potential to 
engender alternative ethical responses to crises of our times. In the specific context of this article, Butler's concept of precarity allows us to think about the relationship between different forms of precarity that frame refugee reception regimes in the Middle East and in the daily lives of Syrian refugee women amidst contemporary Turkish society.

In this larger context, hyper-precarity in labour results from forms of recruitment that cover both forced and deceptive employment, leading to specifically gender-based instances of precarious livelihoods. ${ }^{14}$ For instance, in daily practices, either several constraints are applied to force people to work for a particular employer against their will, or a person is recruited using false promises about the nature of the work, location, wages, etc. Legally speaking, work and life under duress leads to adverse working and living situations imposed on a person by the use of force, threat, penalty, or menace of penalty, and often a combination of several of these means of extortion. These types of labour arrangement may also entail an excessive volume of work, tasks that are beyond what can reasonably be expected to be completed, degrading living and working conditions, limitations on freedom of movement, denial of basic amenities and needs, bonded labour arrangements, and other forms of excessive dependency on the employer. The difficulty faced when leaving one's employer is characteristic of forced labour when leaving entails a penalty or high risk to the worker. Penalty or its threat may be applied directly to the worker or to family members. This can be experienced as coercive and even carried out via threats and violence that could be physical, sexual, or psychological. This includes restriction of workers' freedom of movement due to isolation, confinement, or surveillance, debt bondage or debt manipulation and any accompanying threats against a worker or family members. Withholding of wages or other promised benefits to retain a worker longer than agreed are also commonly used strategies to sustain the submission of workers to forced labour. Retention of passports, identity papers, work permits, or travel documents also refers to situations where workers are forced into bonded labour. If an employer confiscates documents upon the worker's arrival and refuses to return them, this effectively prevents the worker from leaving. Denunciation threats are used, especially in the case of irregular migrant workers, asylum seekers, and sans-papiers. The experiences of Syrian female migrants, refugees, and asylum seekers in the Middle East fall within this category. ${ }^{15}$ Although this group has not generally been recognized as at risk of being coerced into forced work, in the following pages I will make a case to the contrary.

In many cases, asylum seekers in the Middle East are denied permission to work, and they therefore have to survive under highly constrained access to both work and social security. ${ }^{16}$ Henceforth, individuals often feel compelled to seek alternative means of income, often found in informal and unregulated sectors of the economy that shield unscrupulous employers. A growing body of research, albeit conducted under very difficult and curtailed circumstances due to the political climate in host societies, demonstrates that thousands of refugees, forced migrants, and asylum seekers remain in the Middle East with limited access to work, access to education, or recourse to public funds. Pushed into the informal economy to meet their basic needs, these vulnerable populations, and in particular women, become particularly susceptible to exploitation, including forced labour practices and human trafficking.

With reference to Syrian forced migrant women who receive leave to remain in Middle Eastern countries (including legal status, humanitarian protection and discretionary leave, or other interim solutions), these populations are theoretically able to find employment and access benefits and social services. When they are employed, the kind of work Syrian refugee women and girls undertake is typically insecure, temporary, and poorly paid with long and irregular working hours, and unfair dismissals are all too common. ${ }^{17}$ While aggregate data are not yet available, preliminary research conducted by NGOs and public media interviews reveal that Syrian refugee women have begun to cluster in particular sectors-such as cleaning, care, agriculture, food processing, piecemeal cottage industries, hospitality, and sex work-all of which are open to exploitation and insecure. This signals an area of research in need of development.

There are at least three dimensions of precarity that separate this type of work from other forms of labour: non-standard forms of work, wider insecurity, and undocumented and supra-legal practices of labour exploitation. ${ }^{18}$ Ultimately, deregulation and erosion of workers' rights coupled with restrictive welfare and immigration regimes create an environment that allows workplace abuses to flourish. ${ }^{19}$ In this larger context, the potent combination of socio-legal status and gender of an individual determines her rights and entitlements to work, welfare, and residency, conditioning her entry to the labour market entry, shaping her wider social life chances. In turn, this situation foregrounds a differentiated array of rights and protections for different groups of migrants with a marked gender dimension. For instance, Alpak et al. demonstrate the differential distribution of life chances and survival. ${ }^{20}$ In their cross-sectional study in a tent city in Turkey, they concluded that the probability of having post-traumatic stress disorder among Syrian refugees in our sample was 71 per cent, if they had the following features: female; diagnosed with psychiatric disorder; family history of psychiatric disorder; and experience of two or more traumas. 


\section{A Refugee, a Migrant, a Guest, an Illegal Resident, or a New Citizen? The Naming Rituals of Displacement in the Middle East}

Although precarity has become a global phenomenon shaping labour markets in both the Global North and South, a nuanced analysis of the specific national and regional context within which it unfolds is still needed. ${ }^{21}$ Here our context is determined by contemporary Middle Eastern states. Examples of the new Middle Eastern state failing to provide its citizens with basic public services in the context of neo-liberal economic restructuring are as common as the counter examples of the general populace being endowed with massive road construction and urban renewal projects, dams and mines, nuclear power stations and state-of-the-art locally produced weaponry. ${ }^{22}$ Approval for and appreciation of the power of the Middle Eastern state by the masses is as widely chanted as narratives of discontent concerned about privatized infrastructural development projects, marginalized populations, dispossession, and chronic poverty. ${ }^{23}$ In this sense, categorical reliance on neo-liberalism to understand contemporary Middle Eastern states obscures more than it reveals. Instead, attention needs to be paid to specific techniques of governance and relations of power that shape both the discourse and practice of citizenship/rights and membership in contemporary Middle Eastern polities. This, I believe, is best achieved by an engagement with debates on developmentalist/neodevelopmentalist state theory applied to the region.

Lineages of the developmentalist state in the Middle East reach back to the days of independence from colonial and/ or imperial rule during the $195 \mathrm{OS}^{24}$ Its conservative version emphasized growth, provision of social welfare, and building up allegiance to the state through corporatist policies. Confronting the liberal emphasis on state-market alliances, the region also witnessed the emergence of a divergent, socialist form of developmentalism with a strong purchase amongst the Arab nationalist cadres during the 1970s. ${ }^{25}$ Both on the conservative and progressive sides of the spectrum, the formula of a "strong, self-sufficient state" and centralization of governance were the key characteristic of developmentalism. Consequently, the post-independence states in the Middle East, though they brought hopes for inclusive policies and increased rapport between state and society, delivered a heavy and centralized administrative apparatus. ${ }^{26}$ There is little doubt about the strength of contemporary Middle Eastern states in their capacity to coerce, either.

The "old" developmentalist model, also known as national developmentalism, was first established in the Middle East back in the 1960 s and had a distinct militaristic flavour. ${ }^{27}$ Defenders of national developmentalism considered the state as the main agent of social transformation. The new developmentalism continues along these lines, except what is currently considered to be the desired social transformation adheres to a different set of rules and criteria with a distinct emphasis on the absorption of the dispossessed. The model embraced by the Middle Eastern developmentalist state in its latest stage encourages creation of new classes and categories of belonging to ensure a reliable, loyal, obedient public. In particular, instrumentalization of citizenship and membership rights as a means for political leveraging, along with widespread clientelism among the economic elite, led to a unique relationship between different political and economic actors and the state. ${ }^{28}$

Similarities and continuities in citizenship regimes of several Middle Eastern developmentalist states briefly discussed here reveal that there is indeed a persistent inner logic to the reception of dispossessed groups from neighbouring states. This distinct approach is one of complementarity, with reinforced regulatory capacities of the state to decide not only who to let in, but also how and where to situate them once they arrive in accordance with the matrix of labour market needs and contingencies of the political landscape. What is most noteworthy in the example of the reception of the Syrian war victims and refugees is the explicit refusal of immediate interventionist or protectionist moves by the neighbouring states concerning the flow of masses through their borders. Only well past the zenith of the Syrian crisis did Lebanon, Jordan, and Turkey begin to exercise traditional border controls. In this sense, the latest version of the developmentalist state in the Middle East is proven to be pragmatic and highly adaptive to changing regional circumstances. It desires both a strong market and a strong state and doesn't see any contradiction between the two. On the contrary, to absorb the dichotomies created by this anathema of progress and justice delivered by the state and yet through the market, the Middle Eastern states' redistributive goals now include opening up of citizenship and the "right to work" to the dispossessed of the region. Contrary to orientalist takes on migration management in the Middle East, opening borders at times of regional crisis and managing their porousness in an ad hoc fashion is an affirmation of a protagonist "strong state" rather than a weak one.

After intermittent periods of limited democratic rule, the strong states of the Middle East often became quasi-authoritarian regimes. ${ }^{29}$ Installation of industrial capitalism and the organization of society along corporate lines, coupled with the select delivery of social rights and yet the denial of working classes as legitimate political interlocutors coincided with the beginnings of populism in the region..$^{30}$ Almost eighty years since the emergence of the state system in the Middle East, the current discourse of developmentalism seems to be working on the same set of fundamental assumptions concerning state-society relations, yet under a new cloak: the strong state is now presented as the nation itself, as the par 
excellence instrument of the collective desires and dreams for Middle Eastern societies to take their place among the powerful nations on the world stage. Absorption of the regionally dispossessed thus also displays grandeur and might as well as harbouring the possibility of renegotiated borders or new infrastructural investment opportunities.

Across the region, the reduction of membership and citizenship rights to the ballot box is linked with the presentation of the state as an almighty, self-sufficient entity, singlehandedly dictating the political imagination of a future. ${ }^{31}$ Given their distributive commitments and capitalizing on their social policies and basic public service provisions, the gradual closure of decision-making to the public in these aggrandized states was further fortified via their reliance on old paternalistic alliances with the middle classes. Strong charismatic leaders have strengthened their legitimacy in this increasingly self-contained state. ${ }^{32}$ Attempts to formulate national identities from above include instances where the state-and not society-defines the "nation" and the public included the citation of the migrant, the precarious worker, the urban refugee, and the "guests" amongst the grand tally of signs and wonders of national and regional eminence. The new Middle Eastern states' tendency to replace their original emancipatory or redistributive political projects with "power projects" has become all the more visible in the present management of forced migrations and strategic absorption of dispossessed populations. ${ }^{33}$ Holding state power means that newly built alliances and concessions regarding extending rights to new groups may well become the order of the day for serving governments and leading parties. This unique amalgamation of neo-liberal obsession with endless accumulation and statist conception of politics ushered in unprecedented changes in the management of migration and citizenship in the Middle East. Expelling those who are deemed unwanted while accepting the unwanted of others is slowly and silently becoming a tool for sustaining the wave of neo-developmentalism across the region.

\section{The Curious Case of Turkey}

The most commonly cited country in the list of recipient states of Syrian migrants and refugees in the Middle East is Turkey. Turkey is a signatory to the Refugee Convention but with a serious exception clause and entertains a unique status determination regime. From the 1920 s into the mid-199os, the Turkish Republic received more than one and a half million Muslim refugees, ranging from Albanians to Tatars, and their integration was undertaken on an ad hoc basis. During the 1990 os an influx of more than 300,000 Pomaks and ethnic Turks fleeing the persecution of the then-Communist regime in Bulgaria were also quickly absorbed within the immigration and citizenship policy framework. ${ }^{34}$ The government, in line with a law from 1934, considered the latter group to be of "Turkish descent and culture" and granted them the possibility of acquiring Turkish citizenship. In 1991, however, Turkey became the receiving country of the mass influx of refugees who could not be included in that particular law. Close to half a million people fled Saddam Hussein's violence against Kurds and other minorities in northern harsh mountainous terrain and winter conditions, and at a time when the Turkish state still denied cultural and language rights of Kurds within its borders. In what was initially seen as a national security crisis, Turkey tried to deny entry to the displaced. Eventually the government mounted a diplomatic effort, which led the United Nations Security Council to create a safe zone in northern Iraq that would ensure the return of refugees to their homes. Together with the crisis of 1988 that emerged with the arrival of more than 60,000 Kurds fleeing the Halabja massacres, temporarily housed in southeastern Turkey, the "Kurdish refugee problem" was thus the defining moment in modern Turkey's handling of mass influx of the displaced in the region. In November 1994 Turkey proceeded to adopt its first national legislation on asylum. The resultant regulation defined the urgency to respond to mass influxes of refugees before the displaced populations could cross the border into Turkey unless the government was to make a decision to the contrary, as was the case with the Syrians some twenty years later. ${ }^{35}$ With the arrival of Syrians, Turkey has become the sixth-largest recipient of refugees in the world. However, its immigration system is under severe strain, and the status determination process conducted by the UNHCR could take years. To alleviate the problem in the context of the Syrian exodus, UNHCR began to employ the services of a Turkish non-governmental organization, Association of Solidarity with Asylum Seekers and Migrants since July 2013 to speed up the process. ${ }^{36}$ The Turkish General Directorate of Migration Management then implemented the Foreigners and International Protection Law that came into force in April 2014. This new law redefines the rights that asylum seekers and recognized refugees would enjoy in access to public services and employment. ${ }^{37}$ When these policy measures were in place, management of Syrian refugees entered a new phase. ${ }^{38}$

Despite its historical reticence to formally integrate the displaced arriving from the region, by the end of 2011 the Turkish government had thrown its weight completely behind the Syrian opposition and recognized the then-Syrian National Council as the representative of the Syrian people. Turkey's expectation, which was in line with a good part of the international community at the time, was that the Assad regime would not last long. Against this background, Turkey declared in October 2011 an open door policy towards refugees fleeing Syria and developed a legal framework that came 
to be known as "temporary protection." However, things did not go entirely according to plan, and by May 2014 there were 220,000 Syrian refugees housed in twenty-two camps along the Syrian border with another 515,000 registered as urban refugees. ${ }^{39}$ As of early 2018, 3.9 million Syrians were estimated to have sought refuge in Turkey. ${ }^{40}$ The persistence of the conflict well into 2018 and the ever-growing number of urban refugees has created serious challenges for Turkey. Across the region, it is becoming increasingly clear that Syrian war victims and refugees are not about to return home. This brought up major policy issues for the Turkish government, ${ }^{41}$ including whether the government should offer Syrian refugees and migrants residency and citizenship rights and questions addressing urgent education, employment, health, shelter, and integration needs..$^{42}$ The presence of growing numbers of Syrians in Turkey is having a direct impact on host communities economically, socially, and politically. Where Syrians work, how they work, where they live, and for whom they would vote are questions with increasing import, as they now constitute a sizable 5 per cent minority in Turkey.

As much as Turkey's open door policy has been commendable, it has had a weak legal basis and thus a prominently ad hoc quality, ${ }^{43}$ despite the establishment of a new directorate for management of migration, including forced migration flows. ${ }^{44}$ The legal framework encompassing these new policy initiatives was heavily influenced by the Eu directives in place. However, it was adapted to the short- and long-terms goals of the Turkish state. In particular, the regulation adopted in March 2012 that allowed Syrians to stay indefinitely could not be regarded as constituting the basis of a comprehensive policy extending universal protection for more than three million people. ${ }^{45}$ It is a carefully calculated move for partial and selective absorption of the Syrians in Turkey. ${ }^{46}$ More than 800,000 Syrians registered in Turkey have now been protected under a temporary protection regime, being addressed as "guests" or "temporary protection beneficiaries" by the Turkish authorities. Implementation of the temporary protection policy for Syrians means that Syrians are neither refugees nor asylum seekers under Turkish domestic law. In 2013 Turkey adopted its first law that regulates asylum, namely the Law on Foreigners and International Protection, which entered into force in April 2014. Although it promises better protection standards and more safeguards for asylum seekers and refugees, the current legal protection regime of Syrians in Turkey is blind to precarity because it needs to be addressed not by citizenship and immigration regulations but the overall labour regime and under the aegis of administrative law. 47

It is important to remember, however, that Turkey is not the only country affected by the sheer mass of the Syrian exodus and responding to the regional circumstances in an official capacity. Overall, policy restrictions on residency renewals affect the enjoyment of basic rights and freedom for refugees of all nationalities in the region. Access to territory, UNHCR registration, and maintaining livelihoods including formal right to work remain the main challenges faced by Syrian refugees and the waves of dispossessed that were dislocated before them.

\section{The Invisible "Guests": Syrian Women's Precarious Lives on the Move}

Turkey is home to the highest refugee population in the Middle East, with the exception of Israel, having adopted an open door policy for people who come from Syria from 2011 onwards. By December 2016 the number of registered Syrians in Turkey reached 2,783,617 according to the Ministry of Interior Directorate General of Migration Management. Of these, 1,301,026 were Syrian women. The numbers as we neared the winter of 2017 were expected to be well in excess of three million Syrians being settled in Turkey, the majority of whom were women and girls.

The number of displaced Syrians crossing the border into Turkey has dramatically risen with the escalating use of violence employed by the Syrian regime to suppress the revolt. With the influx of huge numbers of Syrians into Turkey, however, anti-immigrant, anti-Arab discourses have surfaced among the Turkish public. Furthermore, due to the Turkish government's openly hostile position to the Syrian regime, Syrian migration became closely linked with Turkish domestic politics and foreign policy. Analyzing the Syrian migrant community in Turkey requires contextualizing it within the political framework of both the host society and the region.

The literature on security and securitization has long been criticized for neglecting the significance of gender as a dimension of security. Literature on security within the international relations discipline has been inadequately engaged in analyzing the pervasive insecurities affecting women during and in the aftermath of armed conflicts. Instead the prevalent discourse often imitates statist discourses on armed conflict. In contradistinction, an examination of gender-related human (in)security issues arising as a result of the armed conflicts would significantly enrich the literature. This change of perspective is critical to understanding the gender-specific social, economic, and cultural barriers that create insecurities for Syrian women refugees and migrants. $4^{8}$

While all Syrians have been affected by violence and conflict in Syria and their lives hasve been uprooted, the group most affected by the ongoing war are women and children. 49 Prior to war and conflict, women and children were already regarded as a disadvantaged group in modern Syria. The war 
has added new forms of precariousness and insecurity to their lives. However, the extremes of either "happiness" for being saved or "poverty" as an endemic condition of their new lives do not reveal much about the future for Syrian refugee and migrant women.

In general, Syrian women face more gender-related problems than Turkish women when attempting to participate in economic, political, and social life as a result of their precarious status. Despite their disadvantages, many Syrian refugee and migrant women have become leaders for their families and have come into prominence as significant actors in the shaping of the economic and social life of Syrian communities in Turkey. Syrian women constitute almost half of the Syrian refugee population in Turkey, and the five-to-eighteen and nineteen-to-thirty-four age groups constitute the majority of Syrian women settled in the country. The youngest age group, those less than five years old, includes close to quarter of a million girls. This indicates that the fertility of Syrian women has remained higher than the Turkish or regional average, despite the problems such as living in a foreign country, having an unstable life, and an uncertain future. Consequently, education, care, and health policies, including the services to be provided for the under-five age group, have become a major concern in a country where the population at large already strives to receive adequate services in these key areas. ${ }^{50}$

In making policies to address the issues facing them, the Turkish authorities are keen to give priority to the traditions, culture, and habits of Syrian women. Many of these traditions, however, are markedly patriarchal and tend to treat women as brides and mothers only, thus limiting their livelihoods to household labour and marriage. A basic mistake made in policy development is the assumption that Syrian women have the same needs and vulnerabilities as women in Turkish society, since both groups are predominantly Mus$\mathrm{lim}$, and they come from neighbouring countries. Not only does Syria have a distinct culture, lifestyle, and customs, but the war in Syria-and the displacement and dispossession that followed-has created unforeseen social practices that affect the lives of those trying to settle in Turkey. Syrian refugee women increasingly find themselves far outnumbering men, as they have gone to join rebel groups, have been killed or captured in combat, or migrated outside of the country separately. In addition, a large proportion of young men have fled the country, fearing the regime's expanding policy of conscription. As such, Syrian women are under increasing economic and social pressure to secure their future.

Considering the realities facing Syrian migrant and refugee women, lack of birth control and abortion services is at risk of leading to high fertility rates, early marriage, and reinforcing the perception of women as the backbone of household and family. As such, there has been limited success for the participation of Syrian women in education and training programs. Girls aged between eleven and seventeen are particularly vulnerable. Needless to say, the leadership of Syrian women, many of whom are heads of households or in polygamous marriages, will help strengthen the economic and social participation of the Syrian population in Turkey. ${ }^{51}$

To put the situation of Syrian women in perspective, it is important to note that only one in five women are in paid employment in Turkey. Overall, the female labour force participation rate stagnated at around 30 per cent, well below the average for the Organisation for Economic Co-operation and Development for the last thirty years, despite rapid urbanization and massive social transformation..$^{52}$ In the case of Syrian refugee women, language issues and genderbased discrimination further complicate matters, so very few women refugees find work other than in poorly paid paid cleaning, housekeeping, or childcare duties, which are outside the formal economy. This combination increases Syrian women's economic dependency and precarity. Women who migrate with their children face further barriers, as they cannot combine childcare and employment when access to education for Syrian children is limited or missing, especially during the earlier phases of the exodus. ${ }^{53}$ This is the context in which we can anticipate early marriage of girls emerging as a survival strategy. However, since marriages under the age of eighteen are not recognized in Turkey, early marriage risks leading to further vulnerabilities for Syrian women. "Early marriages" could be understood as a form human trafficking. Especially in the border provinces, young girls and women are persuaded to come to Turkey with the promise of a better life only to be forced to either marry a Turkish or Syrian man in a religious ceremony to become their unlawful second wives, or forced into prostitution.

Under the state of emergency rules that have curtailed public life in Turkey since August 2017, strict security regulations restrict NGOS responses to refugees and adversely affect services for survivors of gender-based violence. The humanitarian groups in Turkey have focused primarily on emergency response and immediate needs for survival. At this stage Syrians are no longer guests, and the majority of them intend to settle in Turkey permanently. An integration phase orchestrated by public authorities, including language courses, job training, familiarity with public services including educational institutions, and skills-training could facilitate integration of female Syrian refugees into Turkish society. However, most of these services are either absent or are utilized by Syrian men instead in the predominantly patriarchal Syrian and Turkish societies. A gender-responsive plan to integrate female refugees into the social and political life of Turkish society would be the first step in that direction. An educational strategy that offers self-reliance and education 
for female refugees to support themselves and their families is sorely needed. However, given the larger Turkish context, such a strategy is also needed for Turkish women who are not refugees but natives to the land. Similarly, ensuring that all Syrian children are in school is one of the most effective ways to stop child marriage, but again, the same stipulation applies to Turkish girls who are forced into early marriages.

Expanding multi-sectoral service centres and promoting gender sensitivity within the existing humanitarian response to the Syrian crisis is of utmost importance. Given that the lives and social networks of most refugees have been destroyed and that women make up the majority of displaced Syrians, female refugees play a crucial role in overcoming the challenges refugee communities face for years to come. The resilience of female refugees should be matched with opportunities for them to create sustainable and safe communities for their families in Turkey. The problem is that working-class, marginalized urban migrant and rural women in Turkey also face very similar challenges, and the majority of Syrian refugees share their living spaces and life worlds with the underclasses of Turkey who have very similar needs and also suffer from very similar dynamics of gender-segregation themselves.

\section{Conclusion}

Forced labour is not a static or singular situation but is experienced in diverse ways and through complex entry points. ${ }^{54}$ Using the International Labour Organization definition, forced labour is becoming increasingly prevalent in the context of forced migration across the Middle East, the example of Syrian women being one amongst many. Since fieldwork amongst refugee and displaced populations has been restricted, so there has been little research into the experiences of asylum seekers and refugees in this regard. In this article I argued that severe labour exploitation among migrant groups and sans-papiers is to be understood within the wider framework of lack of freedom of movement, precarious livelihoods, and undetermined or semi-legitimate socio-legal status. Employers and traffickers often deliberately use these vulnerabilities to impose to extreme working conditions upon forced migrants that would not otherwise be possible. In this regard, precarious immigration status such as being undocumented, or being a refused asylum seeker foregrounds insecurity, exploitation, and trafficking. A close examination of Syrian women's experiences also revealed that the range of coercive and abusive practices affecting displaced populations have a marked gender aspect. As employers or recruiters exploit the lack of socio-legal status to impose substandard working conditions on workers, particularly those working without permission, the situation also leads to the emergence of new forms of bondage such as human trafficking of young girls and women for the sex trade. While employers could not easily use immigration status to deny improvements or to withhold pay in the context of "regular work," with precarity these practices flourish and often go unreported. In areas such as human trafficking and forced marriages, the situation becomes even more bleak as society often turns a blind eye and normalizes these practices through by silently condoning them. Syrian women who enter the workforce often move between multiple jobs and repeatedly experience employers refusing to pay agreed wages. Finally, those who enter the "irregular work" of the sex trade are not even covered by the standard vocabulary of labour rights. Overall, the threat of denunciation to immigration authorities, police, and risk of deportation, particularly for forced migrants who fear persecution or war conditions if returned to their country of origin, is easily used as a discipliningsocial device in these exploitative working relations (Schweitzer 2014). 55 The lives of the majority of Syrian refugees and asylum seekers in the Middle East are widely recognized as characterized by poverty, insecurity, and in some cases destitution. And yet there is little documentation of women's exploitation in care industries, in marginal sectors, through clandestine marriages and forced sex trade. Hence their lives remain invisible, a malady that neither academia nor NGO work alone could undo. The cost of ignoring gender when analyzing conflict and post-conflict environments is to render Syrian women's lives invisible. To uncover gender-based power relations and deconstruct the so-called gender-neutral approach to precarity in forced migration contexts, we must start with highlighting the differential impact of war and displacement on women and girls. Cessation of hostilities or reaching a safe country for settlement is not synonymous with peace or life with dignity for refugee and migrant women..$^{56}$ As the case of Syrian women in Turkey attests, patriarchy resurfaces after war and crossfertilizes with local forms of oppression and mainstreaming that marginalizes women in novel ways and promotes a conservative return to the status quo ante bellum.

\section{Notes}

1 Brett Neilson and Ned Rossiter, "Precarity as a Political Concept, or, Fordism as Exception," Theory, Culture \& Society 25, no. 7-8 (2008): 71-86; Sue Ferguson and David McNally, "Precarious Migrants: Gender, Race and the Social Reproduction of a Global Working Class," Socialist Register 51 (2014): 1-23.

2 Dimitris Papadopoulos, "The Two Endings of the Precarious Movement," in Mapping Precariousness, Labour Insecurity and Uncertain Livelihoods: Subjectivities and Resistance, ed. Emiliana Armano, Arianna Btove, and Annalisa Murgia, 137-149 (New York: Routledge, 2017).

3 Ilana Feldman, "Anthropology and Humanitarianism in the Middle East," in A Companion to the Anthropology of 
the Middle East, ed. Soraya Altorki, 262-81 (Malden, MA: Wiley Blackwell, 2015).

4 Kim Rygiel, "In Life through Death: Transgressive Citizenship at the Border," in Routledge Handbook of Global Citizenship Studies, ed. Engin F. Isin and Peter Nyers, 62-73 (London: Routledge, 2014).

5 Anne Evans Barnes, "Realizing Protection Space for Iraqi Refugees: UNHCR in Syria, Jordan and Lebanon," New Issues in Refugee Research, Research Paper No. 167, UNHCR, Policy Development and Evaluation Service, 2009, http://www .unhcr.org/research/working/4981d3ab2/realizing-protection-space-iraqi-refugees-unhcr-syria-jordan-lebanonanne.html; Sarah Bidinger, "Syrian Refugees and the Right to Work: Developing Temporary Protection in Turkey," Boston University International Law Journal 33 (2015): 223; Nergis Canefe, "Mülteciden Sığınmacıya, Başvurucudan Göçmen İşçiye: Suriye'den Arafa Giden Yol," Birikim 311 (2015): 17-27 ; Canefe, "Management of Irregular Migration: Syrians in Turkey as Paradigm Shifters for Forced Migration Studies," New Perspectives on Turkey 54, no. 2 (2016): 9-32; Evren H. Ceritoglu, Burcu Gurcihan Yunculer, Huzeyfe Torun, and Semih Tumen, "The Impact of Syrian Refugees on Natives' Labor Market Outcomes in Turkey: Evidence from a Quasi-Experimental Design," IZA Journal of Labor Policy 6, no. 1 (2017); Nazlı Şenses, "Rethinking Migration in the Context of Precarity: The Case of Turkey," Critical Sociology 42, no. 7-8 (2016); Hala Naufal, "Syrian Refugees in Lebanon: The Humanitarian Approach under Political Divisions," European University Institute, Robert Schuman Centre for Advanced Studies, Migration Policy Centre, MPC Research Report 2012/13, http://hdl.handle .net/1814/24835; Jinan Usta and Amelia Reese Masterson, "Women and Health in Refugee Settings: The Case of Displaced Syrian Women in Lebanon," in Gender-Based Violence: Perspectives from Africa, the Middle East, and India, ed. Yanyi K. Djamba and Sitawa R. Kimuna, 82-101 (Cham, Switzerland: Springer International Publishing, 2015).

6 Samira Sami, Holly A. Williams, Sandra Krause, Monica A. Onyango, Ann Burton, and Barbara Tomczyk, "Responding to the Syrian Crisis: The Needs of Women and Girls," Lancet 383, no. 9923 (2014) 1179-81.

7 Susan M. Akram, "Millennium Development Goals and the Protection of Displaced and Refugee Women and Girls," Laws 2, no. 3 (2013), 283-313; Roger Zetter and Camillo Boano, "Gendering Space for Forcibly Displaced Women and Children: Concepts, Policies and Guidelines," in Women, Migration, and Conflict: Breaking a Deadly Cycle, ed. Susan Forbes Martin and John Tirman, 145-73 (Dordrecht: Springer, 2009).

8 Pinar Döner, Adem Özkara, and Rabia Kahveci, "Syrian Refugees in Turkey: Numbers and Emotions," Lancet 382, no. 9894 (2013): 764.

9 Osman Bahadır Dinçer, Vittoria Federici, Elizabeth Ferris, Sema Karaca, Kemal Kirişci, and Elif Özmenek Çarmıklı, "Turkey and Syrian Refugees: The Limits of Hospitality,"
Brookings Institution, International Strategic Research Organization Publication (USAK), 2013, https://www .brookings.edu/wp-content/uploads/2016/06/Turkey-andSyrian-Refugees_The-Limits-of-Hospitality-2014.pdf; Döner, Özkara, and Kahveci, "Syrian Refugees in Turkey," 764; Ahmet İçduygu, "Syrian Refugees in Turkey: The Long Road Ahead," Transatlantic Council on Migration, Migration Policy Institute, Brussels, 2015; Philip Marfleet and Adam Hanieh, "Migration and 'Crisis' in the Middle East and North Africa Region," in Crisis and Migration: Critical Perspectives, ed. Anna Lindley, 24-46 (New York: Routledge, 2014).

10 Juliette Tolay, "Discovering Immigration into Turkey: The Emergence of a Dynamic Field," International Migration 53, no. 6 (2015): 57-73.

11 Talal Al-Qdah and Marie Lacroix, "Iraqi Refugees in Jordan: Lessons for Practice with Refugees Globally," International Social Work 54, no. 4 (2011): 1-14, https://www .researchgate.net/publication/254107493_Iraqi_refugees_ in_Jordan_Lessons_for_practice_with_refugees_globally; N. Ela Gokalp Aras and Zeynep Sahin Mencutek, "The International Migration and Foreign Policy Nexus: The Case of Syrian Refugee Crisis and Turkey," Migration Letters 12, no. 3 (2015): 193.

12 Nurcan Özgür Baklacioglu, "The Violence of Tolerated Temporality," in A Gendered Approach to the Syrian Refugee Crisis, ed. Z. Kivilcim Freedman and NÖ Baklacıoğlu, 42-60 (New York: Routledge, 2017); H. Bauder, "Citizenship as Capital: The Distinction of Migrant Labor," Alternatives 33, no. 3 (2008): 315-33.

13 Judith Butler, Precarious Life: The Powers of Mourning and Violence (London: Verso, 2006).

14 Hannah Lewis and Louise Waite, "Asylum, Immigration Restrictions and Exploitation: Hyperprecarity as a Lens for Understanding and Tackling Forced Labour," Anti-Trafficking Review 5 (2015), 46-67.

15 Kemal Kırışçı, Syrian Refugees and Turkey's Challenges: Going beyond Hospitality (Washington, DC: Brookings Institution, 2014), https://www.brookings.edu/wp-content/ uploads/2016/06/Syrian-Refugees-and-Turkeys-ChallengesMay-14-2014.pdf; C. Lordoğlu, "Türkiye’deki çalışma hayatının bir parçası olarak yabancı çalışanlar [Foreigners as part of the working life in Turkey]," in Türkiyeye Uluslararası Göç Toplumsal Koşullar Bireysel Yaşamlar [International migration to Turkey: Societal conditions, individual lives], ed. B. Pusch and T. Wilkoszewski, 89-100 (İstanbul: Kitap Yayınları, 2010).

16 Suna Gülfer Ihlamur-Öner, "Turkey's Refugee Regime Stretched to the Limit? The Case of Iraqi and Syrian Refugee Flows," Perceptions 18, no. 3 (2013): 191.

17 Ahmet İçduygu, "The Labour Dimension of Irregular Migration in Turkey," CARIM Research Reports 2006/05, Robert Schuman Centre for Advanced Studies, San Domenico di Fiesole: European University Institute (2006); Ahmet İçduygu and Evin Millet, "Syrian Refugees 
in Turkey: Insecure Lives in an Environment of PseudoIntegration," Global Turkey in Europe, August 2016.

18 James Frank Hollifield, Philip L. Martin, and Pia M. Orrenius, Controlling Immigration: A Global Perspective (Stanford: Stanford University Press, 2014).

19 Güvencesizler Hareketi (The precarity movement), Atölye raporları (workshop reports), last modified December 11, 2013, guvencesizlerhareketi.wordpress. com/2013/12/11/15-16-ocak-2011-atolye-raporlari-2/.

20 Gokay Alpak, Ahmet Unal, Feridun Bulbul, Eser Sagaltici, Yasin Bez, Abdurrahman Altindag, Alican Dalkilic, and Haluk A. Savas, "Post-traumatic Stress Disorder among Syrian Refugees in Turkey: A Cross-sectional Study," International Journal of Psychiatry in Clinical Practice 19, no. 1 (2015), 45-50.

21 Robin Broad and Christina Melhorn Landi, "Whither the North-South Gap?” Third World Quarterly 17, no. 1 (1996): 7-17; N. Şenses and S. Erdoğdu, "Irregular Migrant Labour, Trade Unions and Civil Society Organisations in Turkey," in Migration, Precarity, and Global Governance: Challenges and Opportunities for Labour, ed. Carl-Ulrik Schierup, Ronaldo Munck, Branka Likic-Brboric, and Anders Neergaard, chapter 10 (Oxford: Oxford University Press, 2015).

22 Eva Bellin, "The Robustness of Authoritarianism in the Middle East: Exceptionalism in Comparative Perspective," Comparative Politics 36, no. 2 (2004): 139-57; E. Bellin, "Reconsidering the Robustness of Authoritarianism in the Middle East: Lessons from the Arab Spring," Comparative Politics 44, no. 2 (2012): 127-49; James A. Bill, "Class Analysis and the Dialectics of Modernization in the Middle East," International Journal of Middle East Studies 3, no. 4 (1972): 41-112.

23 Arthur Goldschmidt Jr. and Aomar Boum, A Concise History of the Middle East (Boulder, co: Westview, 2015); Jack A. Goldstone, "Understanding the Revolutions of 2011: Weakness and Resilience in Middle Eastern Autocracies," Foreign Affairs 90 (2011): 8.

24 Nergis Canefe, "Post-colonial State and Violence: Rethinking Middle East and North Africa outside the Blindfold of Area Studies," Refugee Watch 45 (2016): 7-31; Vivek Chibber, "Reviving the Developmental State? The Myth of the 'National Bourgeoisie," Socialist Register 41 (2009): 144-61.

25 Hazem Beblawi, "The Rentier State in the Arab World," Arab Studies Quarterly 9, no. 4 (1987): 383; Ali H. Bayar, "The Developmental State and Economic Policy in Turkey," Third World Quarterly 17, no. 4 (1996): 773-85.

26 Nazih N. Ayubi, Over-Stating the Arab State: Politics and Society in the Middle East (London: I.B. Tauris, 1996).

27 Rolf Schwarz, "The Political Economy of State-Formation in the Arab Middle East: Rentier States, Economic Reform, and Democratization," Review of International Political Economy 15, no. 4 (2008): 599-621.

28 Eric R. Wolf and Thomas Hylland Eriksen, Europe and the People without History (Berkeley: University of California Press, 2010).
29 Lisa Anderson, "The State in the Middle East and North Africa," Comparative Politics 20, no. 1 (1987): 1-18; Steven Heydemann and Reinoud Leenders, "Authoritarian Learning and Authoritarian Resilience: Regime Responses to the 'Arab Awakening,'” Globalizations 8, no. 5 (2011): 647-53.

30 Kemal Kırış̧̧, "Between Europe and the Middle East: The Transformation of Turkish Policy," Middle East Review of International Affairs 8, no. 1 (2004): 22-41.

31 Charles Issawi, An Economic History of the Middle East and North Africa (New York: Routledge, 2013); Resat Kasaba, The Ottoman Empire and the World Economy: The Nineteenth Century (Albany: suny Press, 1988).

32 Stephen J. King, "Sustaining Authoritarianism in the Middle East and North Africa," Political Science Quarterly 122, no. 3 (2007): 433-59 ; Timur Kuran, "Why the Middle East Is Economically Underdeveloped: Historical Mechanisms of Institutional Stagnation," Journal of Economic Perspectives 18, no. 3 (2004): 71-90.

33 David Lane and Stephen White, Rethinking the "Coloured Revolutions" (New York: Routledge, 2013); Adrian Leftwich, "Bringing Politics Back In: Towards a Model of the Developmental State," Journal of Development Studies 31, no. 3 (1995): 400-27 ; Kurt Weyland, "The Arab Spring: Why the Surprising Similarities with the Revolutionary Wave of 1848?" Perspectives on Politics 10, no. 4 (2012): 917-34.

34 Kemal Kırış̧ı, "Disaggregating Turkish Citizenship and Immigration Practices," Middle Eastern Studies 36, no. 3 (2000): 1-22.

35 National Legislative Bodies / National Authorities, Turkey: Regulation No. 1994/6169 on the Procedures and Principles related to Possible Population Movements and Aliens Arriving in Turkey Either as Individuals or in Groups Wishing to Seek Asylum Either from Turkey or Requesting Residence Permission in Order to Seek Asylum from Another Country (last amended 2006), January 19, 1994, http://www.refworld .org/docid/49746cc62.html; For a detailed analysis of the regulation, see Kemal Kırışçı, "Is Turkey Lifting the 'Geographical Limitation'? The November 1994 Regulation on Asylum in Turkey," International Journal of Refugee Law 8, no. 3 (1996): 293-318.

36 For a critique of UNHCR's role and status, see Stephan Scheel and Philipp Ratfisch, "Refugee Protection Meets Migration Management: UNHCR as a Global Police of Populations," Journal of Ethnic and Migration Studies 40, no. 6 (2014): 924-41.

37 On the background and consequences of the new law, see Bidinger, "Syrian Refugees and the Right to Work"; Feyzi Baban, Suzan Ilcan, and Kim Rygiel, "Syrian Refugees in Turkey: Pathways to Precarity, Differential Inclusion, and Negotiated Citizenship Rights," Journal of Ethnic and Migration Studies 4, no. 1 (2017): 41-58; Pinar Yazgan, Deniz Eroglu Utku, and Ibrahim Sirkeci, "Syrian Crisis and Migration," Migration Letters 12, no. 3 (2015): 3-14.

38 İçduygu, "Syrian Refugees in Turkey." 
39 UNHCR, "Global Focus: Turkey," http://reporting.unhcr. org/node/2544\#_ga=2.215085203.583954953.1497272120304441541.1497272120.

40 European Commission, "European Civil Protection and Humanitarian Aid Operations," last modified April 6, 2018, https://ec.europa.eu/echo/files/aid/countries/factsheets/ turkey_syrian_crisis_en.pdf.

41 Oytun Orhan and S. Senyücel Gündoğar, "Effects of the Syrian Refugees on Turkey," ORSAM Report 195 (2015), http:// www.orsam.org.tr/files/Raporlar/rapor195/195eng.pdf.

42 Selin Akyüz and Bezen Balamir Coşkun, "Gendered (In) Securities: Refugee Camps in Southeastern Turkey," International Center for Strategic Research and Analysis, February 24, 2015, http://cesran.org/gendered-insecuritiesrefugee-camps-in-southeastern-turkey.html; Baban, Ilcan, and Rygiel, "Syrian Refugees in Turkey"; Jean-François Durieux, "Temporary Protection: Hovering at the Edges of Refugee Law," Netherlands Yearbook of International Law (Dordrecht: Springer, 2015); Papadopoulos, “Two Endings of the Precarious Movement."

43 Kemal Kırışçı, “Provide Comfort' and Turkey: Decision Making for Refugee Assistance," Low Intensity Conflict \& Law Enforcement 2, no. 2 (1993): 10; Kırışçı, "Coerced Immigrants': Refugees of Turkish Origins since 1945, International Migration 34, no. 3 (1996): 385; Kırışç1, "Is Turkey Lifting the 'Geographical Limitation'?: The November 1994 Regulation on Asylum in Turkey," International Journal of Refugee Law 8, no. 3 (1996): 293-318; Kırışç1, "Disaggregating Turkish Citizenship and Immigration Practices," Middle Eastern Studies 36, no. 3 (2000): 1-22; Kırışç1, "Between Europe and the Middle East: The Transformation of Turkish Policy," Middle East Review of International Affairs 8, no. 1 (2004): 1-13.

44 Aras and Mencutek, "International Migration and Foreign Policy Nexus"; Ihlamur-Öner, “Turkey's Refugee Regime”; Murat Yesiltas, “Turkey's Quest for a 'New International Order': The Discourse of Civilization and the Politics of Restoration," Perceptions 19, no. 4 (2014): 43; Murat Daoudov, "Göç Politikasında Söylem-Eylem Dönüşümü ve Belediyele," Conference Publication (2015), https://www.researchgate.net/profile/Murat_Daoudov/ publication/293275569_Goc_Politikasinda_SoylemEylem_Donusumu_ve_Belediyeler_Transformation_ in_Discourse_and_Action_in_Migration_Policy_and_ the_Municipalities/links/577763cbo8aead7ba071dc25/ Goec-Politikasinda-Soeylem-Eylem-Doenuesuemue-veBelediyeler-Transformation-in-Discourse-and-Action-inMigration-Policy-and-the-Municipalities.pdf.

45 Kırışçı, "Syrian Refugees and Turkey's Challenges."

46 Yusuf Akgündüz, Marcel Van Den Berg, and Wolter H.J. Hassink, "The Impact of Refugee Crises on Host Labor
Markets: The Case of the Syrian Refugee Crisis in Turkey," IZA Discussion Paper, no. 8841 (2015); Tuba Bircan and Ulas Sunata, "Educational Assessment of Syrian Refugees in Turkey," Migration Letters 12, no. 3 (2015): 226; Tolay, "Discovering Immigration into Turkey."

47 Meltem Ineli-Ciger, "Implications of the New Turkish Law on Foreigners and International Protection and Regulation no. 29153 on Temporary Protection for Syrians Seeking Protection in Turkey," Oxford Monitor of Forced Migration 4, no. 2 (2015): 28-35.

48 Akyüz and Coşkun, "Gendered (In)Securities"; Şenses, "Rethinking Migration in the Context of Precarity."

49 Nicholas Van Dam, The Struggle for Power in Syria: Politics and Society under Asad and the Ba'ath Party (London: I.B. Tauris, 2011).

50 Senay Özden, “Syrian Refugees in Turkey," Migration Policy Centre, MPC Research Report (2013).

51 Seethereportfrom Yasemin Mert, "Dangerous Journeys:Violence against Women Migrants in Turkey," December 8, 2016, https://www.opendemocracy.net/5050/yasemin-mert/ dangerous-journeys-women-migrants-in-turkey.

52 Aysit Tansel and Elif Oznur Acar , (2016), “The Formal/ Informal Employment Earnings Gap: Evidence from Turkey," in Inequality after the 2oth Century: Papers from the Sixth ECINEQ Meeting (Research on Economic Inequality, volume 24), 121-54 (Bingley, UK: Emerald Group Publishing, 2016).

53 Bircan and Sunata, "Educational Assessment of Syrian Refugees in Turkey"; Mehmet Büyüktiryaki, Fuat Emre Canpolat, Evrim Alyamaç Dizdar, Nilüfer Okur, and Gülsüm Kadıŏlu Şimşek, "Neonatal Outcomes of Syrian Refugees Delivered in a Tertiary Hospital in Ankara, Turkey," Conflict and Health 9, no. 1 (2015): 38.

54 Sin Yee Koh, "Postcolonial Approaches to Migration in Asia: Reflections and Projections," Geography Compass 9, no. 8 (2015): 432-44.

55 Reinhart Schewitzer, “The Making and Unmaking of Irregular Migration: Migrant 'Illegality,' Regularisation and Deportation in Spain and the UK" (Integrim Online Papers, 2014), http://www.integrim.eu/wp-content/uploads/2014/o2/ Schweitzer-the-making-and-unmaking-of-irregularmigration.pdf; Durieux, "Temporary Protection.”

56 Stephen Castles, "Towards a Sociology of Forced Migration and Social Transformation," Sociology 37, no. 1 (2003), $21-62$.

Nergis Canefe is associate professor in the Department of Politics, Public Policy, and Law, York University. The author may be contacted atncanefe@yorku.ca. 